\title{
Alert for bone alterations and low serum concentrations of vitamin $D$ in patients with intestinal inflammatory disease
}

\author{
Lorete Maria da Silva Kotze ${ }^{1}$, Carolina Tabata Costa ${ }^{2}$, Murilo Franco Cavassani ${ }^{2}$, Renato Mitsunori Nisihara ${ }^{2 *}$
}

'Medical School, Pontifícia Universidade Católica do Paraná (PUC-PR), Curitiba, PR, Brazil

${ }^{2}$ Department of Medicine, Faculdade Evangélica do Paraná, Curitiba, PR, Brazil

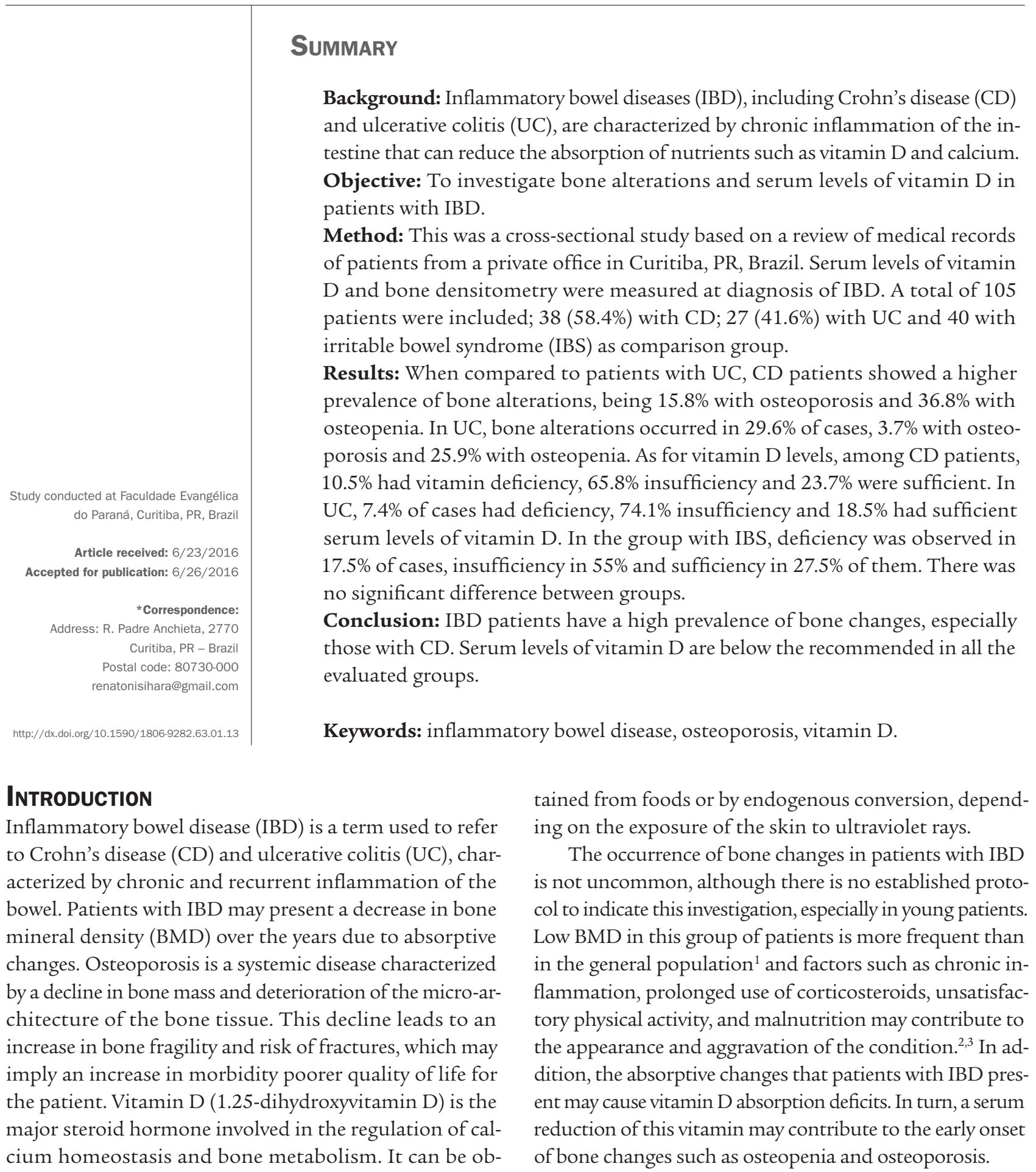


The present study aimed to investigate bone alterations and serum levels of vitamin $\mathrm{D}$ in patients with IBD.

\section{Method}

This is a cross-sectional analytical study approved by the Research Ethics Committee of the Sociedade Evangélica Beneficente de Curitiba (PR), under Opinion Report number 726.050. It was based on the review of medical records of patients followed in a private practice in Curitiba, PR. All consultations and procedures were done by the same professional.

The study included patients with the diagnosis of IBD who had the following information presented in their medical records: serum concentration of vitamin D and results of bone densitometry in the lumbar spine and femur using dual-energy X-ray absorptiometry (DEXA). Incomplete medical records were excluded. Of 120 records analyzed, 15 were excluded because they did not meet the inclusion criteria, resulting in 105 for the study. The patients studied were divided into groups with IBD and a comparison group with irritable bowel syndrome (IBS), as follows:

- CD group: $\mathrm{n}=38$, median age of 39.5 years (range 16 to 73 years), of which 22 (57.9\%) were female.

- UC group: $\mathrm{n}=27$, median age of 39 years (range 16 to 70 years), of which 21 (77.7\%) were female.

- IBS group: $n=40$, analyzed as comparison group, median age of 52 years (between 21 and 77 years), 31 $(77.5 \%)$ were female.

Serum levels of vitamin D and bone densitometry had already been investigated at the time of data collection, which occurred between October 2014 and July 2015 Data collection protocols included: sex, age, disease duration, age at diagnosis, smoking status, history and site of low impact fracture, comorbidities, first bone densitometry report, medications being used until the date of the examination, serum vitamin $\mathrm{D}$ dosage.

All the tests were done in the same laboratory of clinical analyses. Based on the recommended reference values, serum vitamin D levels below $20 \mathrm{ng} / \mathrm{mL}$ were considered deficient, between 20 and $30 \mathrm{ng} / \mathrm{mL}$ were insufficient, and above $30 \mathrm{ng} / \mathrm{mL}$, sufficient.

The assessment for BMD was made using DEXA, which was used to estimate BMD at the lumbar spine and femur. In this method, an X-ray tube and detector are used to scan over the area of interest and generate an image of bone mineral content expressed in grams of calcium. BMD is calculated by dividing the bone mineral content by the bone area. This value was compared with that of the BMD of the healthy young population and the result was expressed as T score. According to the World Health Organization recommendation, the criteria used to define BMD were: normal (T score > -1 ), osteopenia ( $T$ score -1 to -2.5 ), osteoporosis (T score $<-2.5$ ), and severe osteoporosis (fragility fractures, $\mathrm{T}$ score $<-2.5$ ).

\section{Statistical analysis}

The data were prepared in Excel (Microsoft, Office, 2013), organized and analyzed statistically with the aid of the GraphPrism 5.0 package, using the appropriate tests. Fisher's exact tests were used for categorical variables and the Kruskal-Wallis test was used to compare vitamin D dosages, analyzing the three groups under study. A significance of $5 \%(\mathrm{p}<0.05)$ was adopted.

\section{RESULTS}

Table 1 shows clinical and demographic data of the patients. The median disease duration of patients with IBD was 11 years (range 1 to 41 years) and 16 years ( 2 to 36 years) for CD and UC, respectively. There was no significant association between disease duration and the presence of low BMD.

Among the CD group, low BMD was observed in 20 patients (52.6\%), with osteoporosis in six cases (15.8\%) and osteopenia in 14 (36.8\%). In the UC group, bone changes were observed in eight cases (29.6\%), osteoporosis in one (3.7\%), and osteopenia in seven (25.9\%). Comparing the two groups, $\mathrm{p}=0.07$ was obtained. Attention was drawn to the occurrence of bone changes in very young patients. Two patients (one male and one female) with $\mathrm{CD}$ had a diagnosis of osteoporosis as soon as at 14 years of age. Patients with IBS did not undergo bone densitometry because there was no indication for such procedure.

As for smoking habit, nine $(23.7 \%)$ of the patients with CD were smokers, as well as six $(22.2 \%)$ in the group with UC. Among the nine smokers with $\mathrm{CD}$, six were women: two had a history of fracture (one of tibia and one of knee), both had osteopenia on DEXA. Of the six smokers in the group with UC, four were women and one of them had a history of rib fracture and osteopenia. In addition to these patients, in eight other cases (non-smokers), low-impact fractures were observed, with five patients with CD and four women. Three of these women had osteopenia and had had distal metaphysis fractures on the radius and styloid process, ulna, arm, femoral neck, and shoulder. The other patient had osteoporosis and had fractured the humerus. The only man with fracture had a metacarpal lesion and normal bone densitometry. The remaining three patients were women 
TABLE 1 Clinical and demographic data of the patients studied.

\begin{tabular}{|c|c|c|c|}
\hline & Crohn's disease $(n=38)$ & Ulcerative colitis $(n=27)$ & Irritable bowel syndrome $(n=40)$ \\
\hline \multicolumn{4}{|l|}{ Gender } \\
\hline Female & $22(57.9 \%)$ & $21(77.7 \%)$ & $31(77.5 \%)$ \\
\hline Male & 16 & 6 & 9 \\
\hline \multicolumn{4}{|l|}{ Age } \\
\hline Median age (years) & 39.5 & 39 & 52 \\
\hline Interval (years) & 16 to 73 & 16 to 70 & 21 to 77 \\
\hline \multicolumn{4}{|l|}{ Disease duration } \\
\hline Median (years) & 11 & 16 & 4 \\
\hline Interval (years) & 1 to 41 & 2 to 36 & 1 to 23 \\
\hline Smokers & $9(23.7 \%)$ & $6(22.2 \%)$ & $9(22.5 \%)$ \\
\hline
\end{tabular}

with UC: two with normal bone densitometry and both had fractured the foot. In addition, one of them had fractured the hand, the elbow and the knee, thus being diagnosed with osteoporosis. There were no cases of fractures among patients in the comparison group.

Data on serum vitamin $\mathrm{D}$ concentrations in the groups studied are shown in Table 2. No direct correlation was found between age and serum vitamin $\mathrm{D}$ concentration. In the CD group, the median concentrations were $28.7 \mathrm{ng} / \mathrm{mL}$ (range 8 to $70.7 \mathrm{ng} / \mathrm{mL}$ ), with four $(10.5 \%)$ cases of deficiency, 25 (65.8\%) of insufficiency, and only nine (23.7\%) patients had sufficient serum levels. In the group of patients with UC, the median was at $30 \mathrm{ng} / \mathrm{mL}$ (range 11 to $76.7 \mathrm{ng} / \mathrm{mL}$ ). Vitamin D deficiency was found in two $(7.4 \%)$ cases and insufficiency was found in 20 (74.1\%); five (18.5\%) had sufficient serum concentrations. In the group with IBS, the median was at $26.6 \mathrm{ng} / \mathrm{mL}$ (range 11 to $70.5 \mathrm{ng} / \mathrm{mL}$ ). There was no significant difference in serum vitamin $D$ concentrations between the groups studied.

\section{Discussion}

Patients with IBD may have a number of complications, including bone changes that may cause significant clinical repercussions. In our population, there is little research on the presence of these alterations in this group of patients. ${ }^{8}$

Our study found a higher female prevalence for both IBDs, as observed in other Brazilian studies, ${ }^{4-6}$ namely $57.9 \%$ women with CD and $77.7 \%$ with UC. In agreement with the literature, ${ }^{7}$ a higher incidence of IBD was found among young adults, with medians of 39.5 and 39 years for CD and UC, respectively. Regarding age, we observed a high prevalence of low BMD in patients with IBD much earlier than observed in the general population.

Osteoporosis is typically a multifactorial disease. It is most often primary in postmenopausal women and in older people. Secondarily, it may be due to prolonged corti- costeroid therapy, nutritional changes such as poor calcium intake, vitamin D deficiency, alcoholism, and smoking. ${ }^{9-12}$ In our study, we observed that, in women with IBD, fracture cases were more frequent among smokers, a factor already pointed out in another study, ${ }^{9}$ which associated smoking with reduction of BMD and with increased risk of fractures.

Souza et al. described that the number of patients with low BMD between the two groups of IBD is equivalent. ${ }^{3}$ In our study, however, we observed that $C D$ patients had a higher prevalence of bone alterations $(52.6 \% \mathrm{CD}$ and $29.6 \% \mathrm{UC}, \mathrm{p}=0.07)$. This difference may be related to the fact that in CD a greater area of the digestive tract implied in the absorption of nutrients is affected, or even because these patients use corticosteroids more frequently compared with patients with UC. In addition to IBD, other chronic diseases have been associated with osteoporosis, such as celiac disease, systemic lupus erythematosus (SLE), and cystic fibrosis. Silva et al. ${ }^{13}$ showed that $68.3 \%$ of the celiac patients at the time of diagnosis had low BMD, $47 \%$ had osteopenia, and $32 \%$ had osteoporosis. Studying patients with SLE, Bultink ${ }^{14}$ described the occurrence of bone changes in $68 \%$ of them. As for cystic fibrosis, another study ${ }^{15}$ revealed a prevalence of 40 to $70 \%$ of bone alterations in adult patients.

In our study, 13 patients with CD (five women and eight men) and three with UC (all women) used corticosteroids, a risk factor for the occurrence of bone mass changes. ${ }^{1,12,15}$ Two of the female patients with CD with a history of fracture were perimenopausal, another contributing factor to bone loss. ${ }^{9,10}$ Among the patients with UC, only one was menopaused and presented normal BMD.

This study is a warning about the importance of investigating bone changes in all patients with IBD, regardless of the age at diagnosis. As an example, our study includes two patients with CD aged 14 years, treated with corticosteroids and who already showed osteoporosis in their exams. 
TABLE 2 Bone changes and serum concentrations of vitamin D in the patients studied.

\begin{tabular}{|c|c|c|c|}
\hline & $\begin{array}{l}\text { Crohn's disease } \\
(n=38)\end{array}$ & $\begin{array}{l}\text { Ulcerative colitis } \\
(n=27)\end{array}$ & $\begin{array}{l}\text { Irritable bowel syndrome } \\
(n=40)\end{array}$ \\
\hline \multicolumn{4}{|l|}{ Bone densitometry } \\
\hline Presence of bone changes* & $52.6 \%(20 / 38)$ & $29.6 \%(8 / 27)$ & NP \\
\hline Osteoporosis & $15.8 \%(6 / 38)$ & $3.7 \%(1 / 27)$ & NP \\
\hline Osteopenia & $36.8 \%(14 / 38)$ & $25.9 \%(7 / 27)$ & NP \\
\hline \multicolumn{4}{|l|}{ Vitamin D } \\
\hline Median concentration** & 28.7 & 30.0 & 26.6 \\
\hline$(\min -\max , \mathrm{ng} / \mathrm{mL})$ & $(8-70.7)$ & $(11-76.7)$ & $(11-70.5)$ \\
\hline Deficient $(<20 \mathrm{ng} / \mathrm{mL})$ & $10.5 \%(4 / 38)$ & $7.4 \%(2 / 27)$ & $17.5 \%(7 / 40)$ \\
\hline Insufficient (20 to $30 \mathrm{ng} / \mathrm{mL}$ ) & $65.8 \%(25 / 38)$ & $74.1 \%(20 / 27)$ & $55 \%(22 / 40)$ \\
\hline Sufficient (> 30 ng/mL) & $23.7 \%(9 / 38)$ & $18.5 \%(5 / 27)$ & $27.5 \%(11 / 40)$ \\
\hline
\end{tabular}

Vitamin D deficiency can occur due to intestinal absorption impaired by diseases such as IBD. However, it is known to be multifactorial, being influenced by factors such as lack of sun exposure, low intake of foods rich in vitamin $\mathrm{D}$, prolonged glucocorticoid therapy, senility or hormonal changes triggered by menopause. The three groups in our study had inadequate serum levels of vitamin D, and even in the comparison group with IBS, 55\% of the patients showed insufficient concentrations. Premaor et al. ${ }^{16}$ reported that serum vitamin D levels in both young and old adults varied by geographic region, depending on latitude, and were more appropriate near the equator. In the Curitiba area, due to its climatic characteristic of low annual insolation, there is a greater possibility of vitamin D deficiency, as already evaluated by other authors. ${ }^{3,16}$ Regarding serum vitamin D levels, the importance of its replacement in patients with IBD has already been suggested, ${ }^{17}$ since it has a relevant role in the health of this group of patients. In addition to the benefit in bone integrity, an improvement in the immune response is expected and, although not yet fully proven, aid in the prevention of colorectal cancer, a complication that can occur in patients with IBD. ${ }^{17,18}$

We conclude that our patients with IBD had a high prevalence of bone alterations, found to a greater extent in those with Crohn's disease. Additionally, we observed that serum levels of vitamin D were below the recommended levels in all groups studied.

\section{Conflict of interest}

The authors declare no conflict of interest.

\section{Resumo}

Alerta para alterações ósseas e baixas concentrações séricas de vitamina $\mathrm{D}$ em pacientes com doença inflamatória intestinal

Introdução: A doença inflamatória intestinal (DII), como a doença de Crohn (DC) e a retocolite ulcerativa (RU), caracterizam-se pela inflamação crônica no intestino, que pode reduzir a absorção de vitamina $\mathrm{D}$ e cálcio.

Objetivo: Investigar as alterações ósseas presentes em pacientes com DII e as dosagens séricas de vitamina D. Método: Estudo transversal analítico baseado na revisão de prontuários de pacientes com DII de um consultório privado de Curitiba, PR. Em todos os pacientes, foram dosadas as concentrações séricas de vitamina $\mathrm{D}$ e foi feita a densitometria óssea. Cento e cinco pacientes foram incluídos no estudo, dos quais 38 (58,4\%) foram diagnosticados com DC, 27 (41.6\%) com RU e 40 com síndrome do intestino irritável (SII) como grupo de comparação. Resultados: Quando comparados com pacientes com RU, os pacientes com DC apresentaram maior prevalência de alterações ósseas, sendo $15,8 \%$ com osteoporose e 36,8\% com osteopenia. Na RU, as alterações ósseas ocorreram em 29,6\% dos casos, 3,7\% com osteoporose e $25,9 \%$ com osteopenia. Em relação às dosagens de vitamina $\mathrm{D}$, dentre os pacientes com DC, $10,5 \%$ apresentavam deficiência, 65,8\%, insuficiência e 23,7\%, suficiência. Na RU, 7,4\% dos casos tinham deficiência, 74,1\%, insuficiência e $18,5 \%$, suficiência. No grupo com SII, observaram-se deficiência em $17,5 \%$, insuficiência em $55 \%$ e suficiên- 
cia em $27,5 \%$. Não foi observada diferença significativa entre os grupos.

Conclusão: Pacientes com DII apresentaram alta prevalência de alterações ósseas, principalmente aqueles com DC. As concentrações séricas de vitamina D estão abaixo do recomendado em todos os grupos avaliados.

Palavras-chave: doença inflamatória intestinal, osteoporose, vitamina D.

\section{References}

1. Lora FL, Amarante HMB, Pisani JC, Borba VVC, Kulak CAM, Carmes ER Avaliação da densidade mineral óssea em pacientes com doença inflamatória intestinal. Arq Gastroenterol. 2005; 42(4):201-5.

2. Tajika M, Matsuura A, Nakamura T, Suzuki T, Sawaki A, Kato T, et al. Risk factors for vitamin D deficiency in patients with Crohn's disease. J Gastroenterol. 2004; 39(6):527-33.

3. Souza HN, Lora FL, Kulak CAM, Mañas NCP, Amarante HMB, Borba VZC Níveis baixos de 25-hidroxivitamina D (25OHD) em pacientes com doença inflamatória intestinal e sua correlação com a densidade mineral óssea. Arq Bras Endocrinol. 2008; 52(4):684-91.

4. Torres US, Satomi G, Ronchi LS, Netinho JG. Infliximabe na doença de Crohn: experiência de um centro terciário paulista. Rev Bras Coloproctol. 2009; 29(1):38-45.

5. Cohen D, Bin CM, Fayh APT. Assessment of quality of life of patients with inflammatory bowel disease residing in Southern Brazil. Arq Gastroenterol. 2010; 47(3):285-9.
6. Kleinubing-Júnior H, Pinho MSL, Ferreira LC, Bachtold GA, Merki A Outpatients profile with inflammatory bowel disease. ABCD Arq Bras Cir Dig. 2011; 24(3):200-3.

7. Hanauer SB. Inflammatory bowel disease: epidemiology, pathogenesis and therapeutic opportunities. Inflamm Bowel Dis. 2006; 12(Suppl 1):S3-9.

8. Salviano FN, Burgos MGP, Santos EC. Perfil socioeconômico e nutricional de pacientes com doença inflamatória intestinal internados em um hospital universitário. Arq Gastroenterol. 2007; 44(2):99-106.

9. Lewiecki EM, Silverman SL. Redefining osteoporosis treatment: who to treat and how long to treat. Arq Bras Endocrinol Metabol. 2006; 50(4):694-704.

10. Skare TL. Reumatologia: princípios e prática. Rio de Janeiro: Guanabara Koogan; 2007.

11. Lacativa PGS, Farias MLF. Osteoporosis and inflammation. Arq Bras Endocrinol Metabol. 2010; 54(2):123-32.

12. Weinstein RS. Glucocorticoid-induced bone disease. N Engl J Med. 2011; 365(1):62-70.

13. Silva JTP, Nisihara RM, Kotze LR, Olandoski M, Kotze LMS. Low bone mineral density in Brazilian patients at diagnosis of celiac disease. Arq Gastroenterol. 2015; 52(3):176-9.

14. Bultink IEM. Osteoporosis and fractures in systemic lupus erythematosus. Arthritis Care Res (Hoboken). 2012; 64(1):2-8

15. Döring G, Conway SP. Osteoporosis in cystic fibrosis. J Pediatr. 2008; 84(1):1-3.

16. Premaor MO, Furlanetto TW. Hipovitaminose D em adultos: entendendo melhor a apresentação de uma velha doença. Arq Bras Endocrinol. 2006;50(1):25-37.

17. Piodi LP, Poloni A, Ulivieri FM. Managing osteoporosis in ulcerative colitis: something new? World J Gastroenterol. 2014;20(39):14087-98.

18. O'Sullivan M. Vitamin D as a novel therapy in inflammatory bowel disease: new hope or false dawn? Proc Nutr Soc. 2015;74(1):5-12 